\title{
Discrimination and Economic Efficiency in Employee Fringe Benefits: A Clarification of Issues and a Response to Professors Brilmayer, Laycock, and Sullivan
}

\author{
George J. Benston $\dagger$
}

Professors Brilmayer, Laycock, and Sullivan in their Rejoinder have identified several of the areas on which we disagree. ${ }^{1}$ At the outset I hope that needless disputation can be avoided by specifying the legal and ethical values on which I believe we agree. The reader, in any event, will have a basis for judging the extent to which we differ about ends, means, and facts. Fundamentally, I believe that:

1. It is ethically wrong in employment-related decisions for an employer to take a person's race, gender, religious preference, political opinions, national origin, marital status, and other personal characteristics and beliefs into account when they are not germane to the job performed or to be performed. ${ }^{2}$

2. The Equal Pay Act ${ }^{3}$ and Title VII of the Civil Rights Act of $1964^{4}$ forbid invidious discrimination against individuals who are members of designated groups. ${ }^{5}$ Furthermore, I agree with Professor Laycock ${ }^{6}$ that the Constitution's prescriptions establish rights for individuals rather than for groups.

$\dagger$ Professor of Accounting, Economics, and Finance, Graduate School of Management, University of Rochester. Mayer Freed, Daniel Polsby, and Patricia Reagan made valuable suggestions that improved the paper.

1 Brilmayer, Laycock \& Sullivan, The Efficient Use of Group Averages as Nondiscrimination: A Rejoinder to Professor Benston, 50 U. CHI. L. Rev. 222 (1983) [hereinafter cited as Brilmayer, Laycock \& Sullivan, $A$ Rejoinder]; see also Brilmayer, Hekeler, Laycock \& Sullivan, Sex Discrimination in Employer-Sponsored Insurance Plans: A Legal and Demographic Analysis, 47 U. CHI. L. REv. 505 (1980) [hereinafter cited as Brilmayer, Hekeler, Laycock \& Sullivan, Sex Discrimination].

2 I suspect that Brilmayer and her coauthors would agree, for it seems clear that the dispute between the Brilmayer group and myself centers on the question of what factors are germane to employment decisions, and not on whether factors that are not germane may be used therein.

s 29 U.S.C. \& 206(d) (1976).

42 U.S.C. $\$ 2000 \mathrm{e}$ to $2000 \mathrm{e}-17$ (1976 \& Supp. V 1981).

- See 29 U.S.C. $\S 206$ (d) (1976); 42 U.S.C. § 2000e-2(a)(1) (1976 \& Supp. V 1981).

- Laycock, Taking Constitutions Seriously: A Theory of Judicial Review (Book Review), 59 TEx. L. Rev. 343, 378-79 (1981). 
3. The laws are neutral, at least with respect to gender. As I stated in my previous article, they "are not designed to reallocate resources in favor of persons of one sex, or otherwise to benefit or harm persons because of their gender."

With these areas of presumptive agreement in mind, I will consider three broad topics in this response. Because the statutes do not define "discrimination" and because most of the differences I have with Professor Brilmayer and her colleagues derive from the ways we define that term, I will begin by making explicit the concept of discrimination as applied to employment situations generally and to annuity and fringe benefit situations specifically. After that, I will examine our differences regarding the facts about the life expectancies of males and females. I conclude with an analysis of the effects on individual employees of a legal prohibition on the use of sex-distinct life expectancy tables. I hope that this will prove helpful in answering some difficult questions posed by Professor Brilmayer and her colleagues and in clearing up some apparent misunderstandings.

\section{Discrimination and Economic Efficiency in Employment Situations}

Discrimination is an often misused, misunderstood, or at least mis-expressed concept. Many of the important differences between Professors Brilmayer, Laycock, and Sullivan and me stem from our different understandings of the term. This is particularly troublesome because my critics misunderstand the necessary role of economic efficiency in decision making that is not invidiously discrim-

" Benston, The Economics of Gender Discrimination in Employee Fringe Benefits: Manhart Revisited, 49 U. CHI. L. Rev. 489, 493 (1982) (footnote omitted). I base this interpretation of the law on the language of the statutes, which do not state that employers should favor females at the expense of males-indeed, neither designation is mentioned, only "sex" and "opposite sex." See 29 U.S.C. \& 206(d) (1976); 42 U.S.C. \& 2000e-2(a)(1) (1976 \& Supp. V 1981). Likewise, the legislative history of Title VII gives no indication that the intent of the law was to benefit females over males, either individually or as groups. See generally U.S. Equal Employment OppoRtunity Comm'N, Legislative History of TtTles VII AND IX OF THE Crvm Rights Act of 1964 (1968). To the contrary, as two commentators point out:

Congressman Howard Smith no doubt introduced the sex provision as one of many amendments designed to create additional opposition to the entire civil rights bill. . . . The sex provision received little attention and generated slight legislative history. The extensive hearings in the House did not treat the subject at all, and the Senate held no hearings on the bill that was ultimately enacted.

Bernstein \& Williams, Title VII and the Problem of Sex Classifications in Pension Programs, 74 Colum. L. Rev. 1203, 1216-17 (1974). Accordingly, one should not assume that Congress intended to tilt the balance in favor of females. 
inatory. In this part I describe the decision-making process in employment situations where no one practices invidious discrimination, and then I compare that situation with ones in which increasingly restrictive forms of discrimination are practiced.

\section{A. Employment Decisions Without Invidious Discrimination}

Whenever any choice is made, a form of discrimination takes place. In the employment context, this means choosing one person over another or compensating one person more highly than another. Equality, on the other hand, would require that all persons who apply for jobs get them. Their ability to do the work would not be relevant, nor would the cost to an employer of hiring and employing them. Achieving equality in compensation presents special difficulties because each employee's subjective assessment of the value of monetary and nonmonetary rewards for work would have to be the same. Yet each employee may value her or his fringe benefits and perquisites differently..$^{8}$ Even monetary wages might be valued subjectively if some employees viewed compensation as a symbol of intrinsic worth. An employer also must deal with the moral hazard of employees claiming large negative subjective values or complaining about unavoidably distasteful working conditions in order to increase their monetary compensation. The net result is that true equality in hiring and compensation is impossible. For this reason, one must accept the need for choice and hence for some form of discrimination.

At this point in the analysis I am assuming that employers are interested only in wealth maximization. They have no concern about race, sex, marital status, national origin, physical beauty, or any other aspect of an employee's person unless it affects the employee's ability to do the job or the cost of getting the job done. I also assume, for now, that all people concerned with the deci-

- For example, most workers probably prefer more flexible hours, longer coffee breaks, and more vacation time, but these preferences occur in varying proportions. Such nonpecuniary modes of compensation can be said to be subjectively valued. Evaluating and balancing these subjective evaluations in an economically efficient manner is an important aspect of being an employer. Yet the difficulty of assessing such valuations is readily apparent. Consider the case of a woman employee who "knows subjectively that an identically situated man has an equal life expectancy but gets higher periodic benefits" from their retirement plan, the example put forth in Brilmayer, Laycock \& Sullivan, A Rejoinder, supra note 1, at .227. I would argue that the woman's subjective knowledge is empirically wrong. See Benston, supra note 7, at 497-99, 503-05. But in any event, as a result of her belief, she may undervalue the annuity. Her employer then might substitute some other fringe benefit or more direct pay so that she would value her wage package equally with the man's. 
sion-the employer, other employees, customers, and suppliers-are not prejudiced in their judgments, in that they do not understate systematically the value of a person's work or overstate the cost of employing her or him because of the person's race, sex, beliefs, or other personal characteristics.

If an employer is interested in employing people solely because she or he expects their labor to increase her or his wealth, then only those employee attributes that the employer believes serve this purpose will be considered, and employees who produce more, who work more efficiently and reliably, or who require the employer to incur less expense (for items such as pensions and health plans) will be more highly valued. This is not to say that fringe benefits and better working conditions will never be provided. The wealth-maximizing employer naturally will strive to offer and to pay employees the combination of direct and indirect, taxable and nontaxable rewards that the employees will value the most, net of the cost to the employer of administering the wage package. The wage an employee receives is bounded on the top by the value of her or his services to the employer and on the bottom by the alternative employment possibilities or other use of the employee's time. ${ }^{\text {? }}$

The wage setting situation just described implicitly assumes certainty and perfect information-both the employer and the employee know the value of the employee's work and her or his employment alternatives. But the real world is uncertain, and any employer must estimate an employee's worth to her or his business. When an employer estimates incorrectly, she or he will overpay personnel, have to fire employees who do not perform as well as originally expected (a costly procedure), or fail to hire or to retain employees who would have generated profit for the employer. Thus the wealth-maximizing employer has a considerable incentive to predict accurately the performance and cost to be derived from each individual employee. Making predictions is itself costly, however, and an employer must balance this expense against the value of the predictions made. An employment decision can be labeled "economically efficient" only when costs and benefits are equal at

- A professional football player, for example, might be able to get no more than $\$ 20,000$ a year in his next best employment opportunity-teaching English in a college. He also is worth up to $\$ 100,000$ a year to the Chicago Bears. Although the Bears will not pay him more than $\$ 100,000$, they probably can pay less if the only other team that will (or can) hire him is willing to pay no more than $\$ 80,000$. In this situation, the paucity of alternatives permits the Bears to exploit the football player-to pay him less than his value to the club. 
the margin, that is, when each last dollar spent on prediction, direct monetary wages, fringe benefits, other nonpecuniary rewards, and other employment expenses just equals the last dollar generated by the employee's labor. ${ }^{20}$

Becaúse information is costly, it is not desirable, and often not even possible, for an employer to examine and to evaluate every aspect of a person's ability, cost to employ, and other personal attributes. Rather, an employer uses a predictive variable or set of variables that, at the margin, yields predictions that are no more costly to produce and use than they are worth. Variables that efficiently provide predictions of the costs and benefits to an employer often can be derived from past relationships. Thus, an employer's judgments about an employee may well be drawn in large part from the past average relationship between the attributes in question and the employee's value to the employer.

In an important sense, the use of any predictive variable is unfair, since some employees will not perform as the variable predicts. ${ }^{11}$ It matters not whether the attribute considered is education, work experience, age, race, or sex. For example, not all young persons live longer than all persons who are older than they are; not all women of a given age live longer than do all men of the same age; smoking does not cause a uniform decrease in longevity; and some people who have terminal cancer may outlive others who appear to be in perfect health. ${ }^{12}$ Nevertheless, provided that the variables are efficient predictors and not biased or based on stereotypes, the unfairness inherent in using the variables is different from invidious discrimination.

It is important to recognize that when an employer is motivated solely by wealth-maximization, invidious discrimination is counterproductive. The wealth-maximizing employer would consider race or sex in employment decisions only if such personal at-

10 See generally P. Samuelson, Economics 539-42 (9th ed. 1973).

11 Brilmayer and her colleagues suggest "unfairness" in this sense when they assert: "Whenever race or sex is used as a predictor, some individuals are disadvantaged because of a stereotype that is true of others, but not of themselves." Brilmayer, Laycock \& Sullivan, $A$ Rejoinder, supra note 1 , at 234. Although they criticize only the use of race and sex as predictors, the result they would find unfair also flows from using any alternative predictive variable.

12 See Freed \& Polsby, Privacy, Efficiency, and the Equality of Men and Women: $A$ Revisionist View of Sex Discrimination in Employment, 1981 AM. B. Found. RESEARCH J. 583, 625-27, for similar observations and for a critique of the Brilmayer group's incorrect assertion, Brilmayer, Hekeler, Laycock \& Sullivan, Sex Discrimination, supra note 1, at 530-33; Brilmayer, Laycock \& Sullivan, A Rejoinder, supra note 1, at 228-29, that correlations are spurious or meaningless if they relate variables less than perfectly. 
tributes affected or were expected to affect a person's performance or costs of employment. These characteristics would be meaningful in the same way that a person's educational attainments, specific skills, and work experience are meaningful. This is not to say that a wealth-maximizing employer would use race or sex as a predictive variable very often. To my knowledge, there are very few aspects of job performance that can be predicted by these variables alone. For example, most women might not be able to lift as much weight as most men, but a weight lifting test is a better predictor than is gender and would be economical to administer. Indeed, I expect that most instances where race and sex have been used as predictive variables are cases of invidious discrimination (bigotry) or the result of unthinking and inefficient use of irrelevant past relationships (stereotypes). ${ }^{13}$ But, as I discuss in part II below, these are not reasons why insurers use gender as a predictor of life expectancy.

The decision process can be illustrated by applying it to some specific situations. Consider, for instance, a law school dean (or a faculty committee) deciding whom to hire as an assistant professor of law. 14 The dean may "discriminate" among applicants on the basis of the reputations of the undergraduate and law schools they attended, their academic records (particularly whether they were law review editors), positions they have held since graduation (particularly whether they clerked for a "good" judge or worked for a well-regarded firm), and their letters of recommendation. Unless a candidate meets some minimum level on such criteria, she or he usually will not be interviewed or hired for a trial period. Two results of this process should be noted. First, some candidates who are hired will turn out to be poor teachers and researchers; students will suffer; the school's resources will be wasted; and the usually painful process of separation will be required. Second, some people who would have been excellent law professors will not be given a chance to demonstrate that fact. Not everyone lacking a law degree is incapable of teaching and writing about law, and graduates of prestigious schools and former law review editors do not necessarily make the best law professors. The predictive accu-

13 An example of a stereotype is that women are unreliable employees because they tend to quit in order to have babies.

16 Although another example might make my points more dramatically, this one was chosen because of its familiarity to the Brilmayer group and many readers of this Review. See also Freed \& Polsby, supra note 12, at 602-04, for a similar example and further explanation. 
racy of the selection process probably could be improved if the dean and the faculty extensively interviewed each candidate, no matter what the state of her or his credentials. Each candidate also could be allowed to teach for a long enough period to allow the dean and faculty (who would attend the classes and interview the students) to judge completely her or his teaching ability. So that regular students would not be hurt by this procedure, mock students could be hired.

This procedure could be lengthened and individualized until job performance could be predicted almost perfectly. Nevertheless, the record-based hiring procedure still would be followed because it predicts satisfactorily (i.e., efficiently), considering the costs of the "better" (i.e., more individualistic, perhaps more highly predictive) system described. Because the criteria are based on past experience with other candidates, grouped according to the schools they attended, the records they achieved, and other such factors, record-based hiring necessarily violates the admonition of Professor Brilmayer and her colleagues to ignore average group differences in order to provide individual consideration to people who differ from the average. ${ }^{15}$ In fact, none of the usual criteria used to select new law professors meet Professor Brilmayer and her coauthors' requirements that a predictor inherently (genetically or otherwise) affect every applicant or that there be a demonstrated, undeniable causal relationship between the criteria and an applicant's success as a law professor. ${ }^{16}$ Law schools (the market) use the traditional criteria and not the alternatives $I$ have suggested, however, both because the criteria are relevant, that is, they satisfactorily predict the desired traits, and because they are economically efficient. ${ }^{17}$

Another example more relevant to annuities, the issue we are debating, is the use of a person's age as a variable to predict life expectancy. According to many of the criticisms of Brilmayer and her colleagues, age should not be used. The correlation between age and mortality is based on the average experience of persons of a given age, on the assumption that this experience provides individual expectancies for every member of the age group; for a per-

15 See Brilmayer, Laycock \& Sullivan, A Rejoinder, supra note 1, at 234-35.

${ }^{26}$ See id. at 235.

17 See id. at 229, where the Brilmayer group misstates my decision rule as using "the cheapest predictive variable available," when the rule really is to select the predictive variable that, when used efficiently (that is, marginal costs and marginal benefits from using it are equal) yields the maximum net benefits. 
son of a given age, the expected relationship is as much an individual characteristic as is a person's sex. But a person's age at any moment in time is immutable, and my critics view any categorization based on immutable characteristics as inherently suspect. ${ }^{18}$ Because not all young people outlive all people who are older, it follows from their arguments ${ }^{19}$ that using age to set annuity premiums or to calculate pension benefits is unfair to any young individual whose actual longevity differs from her or his group average. Finally, the rationale of the Rejoinder suggests that because there is no definitive proof of a causal connection between age and longevity such that all people of the same age will live the same number of years, the use of age as a predictive variable is unfair. ${ }^{20}$

But if age were not taken into account in each annuity calculation, individual older people would be the victims of a form of reverse discrimination; ${ }^{21}$ even without proof of a causal connection between age and mortality, ignoring age would be unfair. Moreover, market pressures "force" (in the sense of reward) all insurers to use age this way, not because there is no more precise way to predict longevity, but because age is relatively easy to verify, is inexpensive to administer, and yields accurate predictions compared to alternative procedures; hence it is an economically efficient predictor. As a consequence, this efficient age discrimination in insurance is widespread, ${ }^{22}$ and in fact I would be surprised if Professor

1s Id. at 234 .

19. Id.

20 The Rejoinder implies that any decision-making process that is based on predictors without absolute causal explanatory power is intolerable. See id. at 228-29, 235 . I see two problems with this view. First, it seldom would permit decisions to be made at all. Second, in the particular context of gender and longevity, although a categorical affirmation is not possible, the existing evidence overwhelmingly supports a causal link between the two. See infra part III.

21 In such a situation, annuity premiums would be the same for both older and younger persons. Experience dictates that most of the older annuitants would die sooner than would their more youthful counterparts. The result would be the aged subsidizing the young. Because this redistribution of wealth would take place under the rubric of "equality" on the basis of age, it can be viewed as a form of reverse discrimination. As long as the correlation between age and longevity is strong enough to make the predictor efficient, discrimination is inevitable if it is not used.

22 See Brilmayer, Laycock \& Sullivan, A Rejoinder, supra note 1 , at 231. Once one accepts the fact that any choice or selection process involves "discrimination," see supra text following note 8 , one also must conclude that efficient discrimination is to be preferred in order to avoid a waste of society's resources. The criticism by Professor Brilmayer and her coauthors of efficient discrimination, see Brilmayer, Hekeler, Laycock \& Sullivan, Sex Discrimination, supra note 1, at 528; Brilmayer, Laycock \& Sullivan, A Rejoinder, supra note 1, at 228-31, fails to distinguish between invidious discrimination (bigotry) and the type of efficient discrimination that occurs when insurers make decisions on the basis of age or sex. The distaste expressed by the Brilmayer group toward the use of efficient predictors 
Brilmayer and her colleagues would want a legal bar on the use of age as a predictor of mortality.

As this point, they may object that the age example is inapposite and that sex is different. For one thing, as Professor Laycock in particular argues ${ }^{23}$ and as the Rejoinder emphasizes, ${ }^{24}$ sex is "really" immutable. But returning to the law school example, by the time a person is old enough to be a law professor, intelligence and academic performance are also immutable. Someone who dropped out of college or failed law school because of intellectual inability is unlikely to be able to alter her or his academic performance so as to qualify as a law professor. Acquisition of most of the minimal qualifications necessary for one to be considered for a law professor's job is impossible for most people; their position in this respect is immutable. ${ }^{25}$

Another objection that Professor Brilmayer and her colleagues might raise is that sex is different from age because historically it has been an abused classifier. ${ }^{26}$ But this also has been the case with age. ${ }^{27}$ Moreover, recall that the analysis up to this point has assumed that neither employers nor anyone else discriminates invidiously. In this context, "abuse[] as [a] classifier[]"28 has no meaning unless the decision maker is incompetent. As I discuss below, objections to using sex as a predictive variable must be based on its use either for invidious purposes (bigotry) ${ }^{2 \theta}$ or in situations where the decision maker is believed to be incompetent because she or he

may be predicated in part upon their misunderstanding of the meaning of this term. The market forces the use of efficient predictors; that much is clear, but Brilmayer and her colleagues misapprehend how this occurs. They contend that " $[t]$ he market pressures all insurers to use sex, not because it is relevant in and of itself, but because it is the cheapest predictive variable available." Id. at 229. If the market functioned in such a way, efficiency would never be achieved because cost considerations in isolation would result in the use of inconsistent or inaccurate predictors. Rather, the market forces decision makers to find that point of equilibrium at which the best predictor, when used, does not cost more than it is worth when compared to other possible next best predictors.

23 See Laycock, supra note 6, at 383, 386-87.

"See Brilmayer, Laycock \& Sullivan, $A$ Rejoinder, supra note 1, at 234.

${ }^{25}$ Most of these people would find it easier, though probably not as desirable, to change their sex than to graduate from a prestigious law school with experience as a law review editor.

${ }^{28}$ See Brilmayer, Hekeler, Laycock \& Sullivan, Sex Discrimination, supra note 1, at 526-27; Brilmayer, Laycock \& Sullivan, $A$ Rejoinder, supra note 1, at 234; Laycock, supra note 6 , at $382-86$.

${ }^{27}$ See Age Discrimination in Employment Act, 29 U.S.C. $§ 621$ (1976) (preamble to act stating congressional findings of age discrimination in employment).

28 Brilmayer, Laycock \& Sullivan, A Rejoinder, supra note 1, at 234.

29 See infra notes $39-44$ and accompanying text. 
bases decisions on false, and hence inefficient, stereotypes. ${ }^{30}$

\section{B. Employment Decisions With Invidious Discrimination}

Having described the decision-making process where there is no invidious discrimination, I would like to trace out the differences that appear under three increasingly restrictive assumptions: (1) the employer does not intend to discriminate invidiously but may do so unintentionally; (2) people other than the employer-perhaps other workers, suppliers, and customers-have a preference or taste for invidious discrimination; and (3) the employer has a preference for invidious discrimination.

1. Invidious Discrimination Practiced Unintentionally. Assuming that employers and insurers wish to maximize their wealth, by definition they would not want to discriminate invidiously. If they did so, they would be making decisions based upon variables that predict inefficiently. But they could make incorrect assessments unintentionally concerning the relationship between a person's sex, race, age, or national origin and her or his job performance, cost of employment, or mortality. Such erroneous

so See infra note 45 and accompanying text.

Brilmayer, Laycock \& Sullivan pose four hypothetical situations that they apparently believe are analogous to using sex-distinct mortality tables for annuities. These are using (1) a potential borrower's gender as a predictor of credit repayment, Brilmayer, Laycock \& Sullivan, $A$ Rejoinder, supra note 1, at 228; (2) a prisoner's race as a predictor of recidivism in parole decisions, id.; (3) ethnicity as a predictor of a college applicant's grade-point average, id.; and (4) race as a predictor of drug use by a prospective employee, id. at 229-30. My response is fourfold. First, their hypothetical situations implicitly assume that using sex, race, or ethnicity as predictors always leads to unfair results because other variables could have been used at least as effectively as predictors. But as I already have shown, using any other predictors also leads to unfair results in the sense that some individuals will differ from the predicted relationship. Second, I agree that these personal characteristics have been used in the past for invidious purposes. Consequently, as I already have stated, Benston, supra note 7, at 493, "those who use the criteria have the burden of demonstrating that such use is not based on bias and does not result in unfair discrimination against individuals." I show in part II below, however, that there is no reason to believe that insurers or employers use sex-distinct mortality tables as a means of practicing invidious discrimination against females. Indeed, Brilmayer and her colleagues have not explained why insurers charge women less than men for life insurance. Third, these hypotheticals, which posit the use of only a single predictive variable to attain or avoid a particular trait, ignore reality. Unlike the prediction of mortality, factors other than sex, race, and ethnicity undoubtedly are efficient predictors of credit-worthiness, recidivism, and performance in college. Finally, the choice of hypotheticals ignores the fact that there are situations where the predictive power of sex, race, or ethnicity is overridden because of paramount social concerns. The deprivation of liberty in the recidivism context is such a case. But my critics have not identified any social concerns on which a prohibition against using sex-distinct mortality tables might be based. In part IV I identify policy reasons that argue against the abolition of sexdistinct mortality tables. 
perceptions might be based on incomplete experience with members of the particular group (e.g., "once I hired a black and he insulted the customers") or on a previous correlation that has since changed (e.g., women now seldom die from childbirth). If the decision makers really are wealth-maximizers, they have a considerable incentive to correct such misperceptions, but they could be incompetent or lack access to more accurate information. ${ }^{31}$ If incompetence among decision makers is prevalent, society may wish to act through legislation in order to prevent the deadweight loss caused by the use of inefficient predictive variables.

2. People Other Than the Employer Have a Preference (Taste) for Invidious Discrimination. Invidious discrimination in employment can occur as a consequence of demands by employees, customers, and possibly suppliers. Some people just prefer to be bigots-they have a taste for invidious discrimination. They simply may dislike some groups of people ("minorities"), such as blacks, women, people with foreign names or accents, or people with opinions about life and politics that differ from their own. These "philosophical" bigots either may refuse to work with or be served by minorities; ${ }^{32}$ alternatively they may be willing to deal with minori-

s1 The Brilmayer group apparently believes that it has more information than insurers have. They claim, by way of a hypothetical example, see Brilmayer, Laycock \& Sullivan, $A$ Rejoinder, supra note 1 , at 225, and citations to some literature, see Brilmayer, Hekeler, Laycock \& Sullivan, Sex Discrimination, supra note 1, at 558, that the reason for the measured longer life of women is that men tend to be self-destructive. If these specific individuals could be identified, they say, Brilmayer, Laycock \& Sullivan, A Rejoinder, supra note 1, at 226,234 , insurers would realize that it is not a person's gender, but her or his self-destructive behavior that is responsible for an earlier death. The Brilmayer group does not say just how these people are to be identified. Nor do they acknowledge that not all people who smoke, drink, take risks, are very ambitious, or otherwise live self-destructively die earlier than those who do not. Consequently, even if these "self-destructors" could be identified and self-destructiveness used as the criterion of decision, insurers still would have to discriminate (unfairly, according to the Brilmayer group's analysis) against or in favor of (depending on whether life insurance or annuities are at issue) those who do not conform to past averages. Furthermore, if it is more expensive and/or less accurate to use various measures of self-destructive behavior rather than gender as predictors, as seems to be the case, see Benston, supra note 7, at 517-19, several negative results follow from forbidding reliance on gender as a predictor. First, all annuitants would receive lower benefits, due to the decreased cost efficiency of the predictors. Second, there would be a shifting of the effects of discrimination from one group to another, that is, from women who currently do not live as long as their predicted life expectancy to men and women who are not identified as selfdestructors but who nevertheless die earlier than predicted. For additional discussion of the redistributive effects of a prohibition of sex-distinct mortality tables, see infra notes 70-80 and accompanying text; Freed \& Polsby, supra note 12, at 626-27.

${ }^{32}$ To some, particularly those who have experienced invidious discrimination, it may seem callous to say that such discrimination reflects a preference, a taste, or even a philosophical belief on the part of other people, whom I have labeled philosophical bigots. But if a law is enacted that forbids the exercise of such beliefs, it should be recognized that the 
ties only in return for higher wages or lower prices. ${ }^{33}$ Some employees may be "opportunistic" rather than philosophical bigots. They rationally conclude that they can reduce the supply of competitors for their jobs by refusing to work with minorities. ${ }^{34}$

One result of either type of bigotry is that employers (who, it is assumed at present, are not bigots) must pay higher wages or receive less for the products and services they sell. This result will occur, however, only if the bigoted employees or customers have the power to enforce their preferences on the employer..$^{35}$ If the bigots do not have this power, they must bear at least some of the costs of their preferences, since their value to the employer is reduced much as it would be if they demanded instead some other type of costly work benefit, such as longer coffee breaks or more paid sick leave. If they are willing to pay these costs, the wealthmaximizing employer will accede to their demands. In either event, however, the minorities are disadvantaged.

Another result is that some employers can benefit from the bigotry of others. As a consequence of the bigotry of one employer's workers or customers, some other employers might face a greater supply and quality of labor or of demand for their products. If bigotry prevents blacks from getting jobs in factories, for example, they would be available in greater numbers as farm workers. Hence, farm employers could benefit from encouraging bigotry among white factory workers. But it is important to emphasize that the factory owners would still lose. For this reason, it is not in their wealth-maximizing self-interest to foster or practice invidious

preferences of some people ("liberals") are being legally imposed on others ("bigots"). I must admit that my use of the term "bigot" to describe those who invidiously discriminate against others reflects my own taste, since a bigot is defined as "1. a person who holds blindly and intolerantly to a particular creed, opinion . . . 2. a narrow-minded, prejudiced person." Webster's New World Dictionary of the American Language 139 (2d ed. 1970). I also should state that I consider myself to be a liberal and would impose my preferences on bigots for the sake of minorities and my own ethical standards. I believe that the harm done to those against whom there is invidious discrimination is much greater than the harm done to those forbidden to practice bigotry. Furthermore, although I believe that the imposition of moral imperatives by government fiat establishes precedents that I sometimes regret, the action by Congress in outlawing employment discrimination probably was desirable.

ss See R. Posner, The Economics or Justice 351-54, 359-63 (1981).

36 For example, while some white male coal miners may be philosophically opposed to having blacks and women work in the mines, others opportunistically realize that they would not be as highly paid if the minorities could offer their services as miners rather than only as laborers and waitresses.

${ }^{35}$ This power could be derived from such sources as labor unions that can call strikes or boycotts, consumer organizations that boycott products and stores, individual and governmental (police) harassment, and community pressure. 
discrimination, except to avoid any greater costs that their bigoted employees or customers could impose. ${ }^{36}$

Finally, employers whose workers or customers are bigots might benefit from laws that make invidious discrimination illegal. If the employer could mollify the bigoted workers and customers by blaming the employment of minorities on "the law," she or he could get the best workers (considering all costs and benefits at the margin) without having to pay off the bigots. A law prohibiting invidious discrimination would be welcomed by these employers, as long as they could be sure both that their competitors would obey the law and that it was not administered in a way that imposed more costs than benefits on the employer and on nonbigoted employees. Thus a nonbigoted employer would not benefit from a law, for example, that coerced her or him into hiring members of a minority group who were not actually qualified, or that forced her or him to discriminate invidiously against some employees, as would occur were unisex mortality tables mandated for annuity benefits. An antidiscrimination law also would be welcomed by minorities. First, the law would increase the cost to bigots of expressing their taste (if it would not prevent this behavior altogether). Second, it would force up the wages paid by employers who had not previously discriminated invidiously in employment: because minorities would have more job opportunities, the nondiscriminating employer would face a smaller labor pool and therefore would have to pay higher wages to attract employees. For the same reason, however, though minority employees would still be valuable to the employer who was not a bigot, they would be valued less than when the employer could pay them lower wages.

3. Bigoted Employer. Finally, we can consider the case of a bigoted employer who prefers not to employ minorities. Such an employer forgoes the opportunity of hiring the best person for the job if the person is a member of a minority group. Part of the cost of this bigotry is borne by the bigoted employer, who sacrifices wealth in exchange for exercising her or his preference for bigotry. The minority person who is denied an opportunity also suffers part of the cost, but receives no offsetting benefit (unless not working for a bigot constitutes a sufficient reward). Again, legislation forbidding invidious discrimination (if not dysfunctionally written or

se It should be noted that, given the existence of philosophical bigotry, minorities are better off if other employers opportunistically take advantage of the situation to employ them at lower wages. The alternative is no employment at all. Of course the best alternative would be no bigotry. 
administered) would be desirable. Minorities would be better off because of higher wages and increased employment opportunities, and bigoted employers would be wealthier, if no happier, because they would be forced to make employment decisions based solely on considerations of wealth maximization.

\section{Summary}

This discussion has examined the decision-making process in employment situations, tracing the implications of invidious and noninvidious discrimination. If invidious discrimination is not practiced, deliberately or inadvertently, the use of an employee's or applicant's race, sex, or age as a predictive variable is no more or less unfair than the use of educational credentials, previous experience, or intelligence test scores; use of any of these variables, whether or not it is labeled as "immutable," may be unfair to a given individual because it results in understating the person's real employment value. The important question, therefore, is not whether people are treated unfairly in this sense or whether decisions are made efficiently, but whether the evaluation of the employee's economic value is based on a biased, incorrect use of a predictive variable-any variable.

For these reasons, when the Brilmayer group accuse employers and insurers of discrimination for using gender to predict life expectancy, they must provide evidence either of bigotry or of the failure of gender to predict life expectancy efficiently. Considering the historical experience of females, it is likely that some employers and other employees have a preference for invidious discrimination against women. But even if that were the case, one must provide at least some reasoning or evidence that shows how and why sex is misused as a predictor of mortality to the disadvantage of females. I will present considerable evidence in the next part to show that sex is not used to discriminate invidiously against females with respect to annuities.

\section{Discrimination in AnNuities and Life Insurance}

Insurance exists because there is uncertainty. If it were known for certain how long people would live and whether they would suffer accidents or become ill, no one would purchase insurance and no one would sell it. Nothing could be gained that could not be obtained from ordinary planning for known events, and both parties would have to incur needless administrative and transaction costs. In addition, insurance sellers would be faced with an insolu- 
ble moral hazard problem, because only people who knew that they would die later (or sooner) than expected would buy annuities (or life insurance). ${ }^{37}$ Insurers exist because it is possible to reduce uncertainty for individuals while largely avoiding the costs of moral hazard by assessing and pooling risks. Variables that efficiently predict the risks that each individual is expected to impose on the insurer (and, hence, on the other persons insured) enable the insurer to charge each person for the approximate costs of providing her or him with insurance.

As discussed above, ${ }^{38}$ nonbigoted insurance companies and nonbigoted employers who provide retirement benefits would want to use variables that are economically efficient predictors; they would be indifferent about an insured person's sex, race, or other personal attributes unless those characteristics were efficient predictors of life expectancy. It is possible, however, that some employers and insurers want to discriminate against females. Accordingly, I turn to an examination of the possibility that employers and/or insurers use segregated mortality tables to discriminate invidiously against females.

\section{A. Invidious Discrimination Against Females by Employers}

Discrimination against female employees by their employers could take two forms. The most effective form, from the viewpoint of a philosophical bigot, simply is to refuse to employ women. This form of bigotry is irrelevant to the present debate because retirement benefits are paid only to former employees.

The other way employers might discriminate would be to pay less to female employees than to males. Females could be injured either by being charged more than the cost for their benefits or by receiving lower benefits than those to which their contributions entitle them. In fully vested defined contribution plans, there is presumptive evidence of nondiscriminatory treatment of women because the same percentage of each covered employee's wage is paid into the plan..$^{39}$ When an annuity plan is not fully vested immediately, as is generally the case for defined benefit plans, the em-

37 Similar problems would exist for all forms of insurance in the absence of uncertainty.

3s See supra notes 8-13 and accompanying text.

30 When females get invidiously discriminatory lower wages, the employer's retirement contributions also are lower. The real problem, however, is not lower retirement benefits, but the base salary. In this situation, attention should be directed towards the payment of invidiously determined wages, for if that is corrected, the inequality in contributions also is corrected. 
ployer's cost for the annuity promised to each employee must be calculated. The cost is a function of the amount that must be set aside to pay the promised pension multiplied by the probability that the employee will remain with the company long enough to get vested rights to the pension. When an amount proportional to an employee's wage is promised as a periodic payment for life (as is usual), and when a woman is expected to live longer than a male of the same age (an assumption on which sex-distinct mortality tables are based), the cost to the employer is greater for a female than for a male. So long as female employees do not contribute more than enough to offset the employer's extra cost, the employer's intent is benign. The extra cost for the female's annuity results from the longer female life expectancy reflected in the sexdistinct mortality table, not from any invidious intent to discriminate against females on the part of the employer. ${ }^{10}$ Because virtually all insurance companies use sex-distinct mortality tables, ${ }^{41}$ an employer's purchase of a plan from a company that does so tells little about the employer's discriminatory intent. The question whether the use of sex-distinct mortality tables is evidence of invidiously discriminatory intent, therefore, is best analyzed by looking at the practices of the insurance companies.

\section{B. Invidious Discrimination Against Females by Insurers}

Insurance companies cannot reasonably be accused of being philosophical bigots with respect to females. They only sell insurance to them or on them; they do not otherwise come in contact with the people of whom they are alleged to be intolerant. ${ }^{42}$ Ac-

10 If the employer bears this extra cost attributable to females without passing it on to female employees, she or he discriminates against males, since in effect, the compensation for male employees is less than that for female employees. The bottom line is difficult to determine, however, since the vesting provisions may operate to reduce the number of women who actually collect retirement benefits. This would be the case if women were in fact less likely to remain with the company until their benefits vested.

4This practice is followed except in situations where courts have mandated otherwise, e.g., Spirt v. Teachers Ins. \& Annuity Ass'n, 691 F.2d 1054 (2d Cir. 1982), petition for cert. filed, 51 U.S.L.W. 3394 (U.S. Nov. 9, 1982) (No. 82-791); Norris v. Arizona Governing Comm. For Tax Deferred Annuity \& Deferred Compensation Plans, 671 F.2d 330 (9th Cir.), cert. granted, $103 \mathrm{~S}$. Ct. 205 (1982), or where they have been directed by employers not to do so. The University of Minnesota, for example, adopted a merged-gender table in 1982. The university's director of employee benefits, Harold J. Bernard, says that as a result, retirement payments to female faculty members will increase by about five percent, and those to male faculty members will decrease by five percent. The plan is insured by Minnesota Mutual Life Insurance Company and Northwestern National Life Insurance Company. Chron. Higher Educ., Oct. 13, 1982, at 25, col. 2.

12 It is conceivable that some virulently bigoted insurance agents would refuse to deal 
cordingly, if invidious discrimination is practiced against females through the use of sex-distinct mortality tables, it must be either opportunistic or unintentional.

If invidious discrimination against females is opportunistic, it should be most evident in those insurance products where it would be most profitable to the insurance companies. Employer-purchased annuities are not such products. Employers are wealth maximizers interested in the most economically efficient product; whether or not an employer is a bigot or attempts to exploit the bigotry of other employers, she or he would not want to be exploited by an insurance company. Rather, if invidious discrimination is practiced, it is much more likely to be found in the pricing of individually purchased life insurance and annuities (for which sex-distinct mortality tables are used). The evidence, however, is inconsistent with the existence of any such discrimination. Almost all insurance companies charge females less for life insurance than they charge males, all other things being equal. These lower life insurance premiums are based on the same sort of sex-distinct mortality tables as are used to calculate annuity premiums, further adjusted for the expectation that males and females who purchase annuities will live longer on average than people who buy life insurance. ${ }^{43}$ In 1981 the dollar amount of premiums paid to American life insurance companies for individually purchased life insurance on women's lives was about $87 \%$ more than the amount collected for women's individually purchased annuity contracts; the premiums on men's life insurance in 1981 were $331 \%$ greater than the premiums on men's annuity contracts. ${ }^{44}$ Therefore, if the insurance companies' use of sex-distinct mortality tables is evi-

with women or write policies on their lives or health. But in this event, the company would not need sex-distinct tables in order to discriminate, since it would have no female customers.

43 These same tables are used for employer-purchased life insurance and annuities, sometimes adjusted on the basis of the experience of the group of employees who are insured.

44 Premiums on ordinary life insurance and individual annuity contracts are taken or derived from statistics in AM. Council of Life INS., Lire INsurance FAcT Book 56 (1982). Life insurance premiums paid on male and female lives are based on face amounts purchased. Id. at 11 . These percentages underestimate somewhat the premiums for females, since their premiums are lower for the same face amounts. This may be offset, however, because men purchase about $12 \%$ more higher-premium term insurance than females do. Am. Council of Life Ins., Life Insurance Buying 13 (1979). Annuity premiums are estimated from the amounts of annuity payments that were received by annuitants between 1971 and 1976. Society of Actuaries, 1979 Report on Mortality and Morbidity Experience 124-219 (Tables D, E, F, G, H) (1980) (unpublished report on file with The University of Chicago Law Review). 
dence of invidious discrimination on the basis of sex, the conclusion must be that insurance companies are discriminating against males.

The evidence also belies any assertion that insurance companies use sex-distinct tables because they are misled by incorrect, stereotyped beliefs about female mortality. The history of the industry in the United States and in other countries shows that mortality tables have been revised from time to time in the light of available statistical evidence and not in accordance with bigoted beliefs about males and females. ${ }^{45}$ Any insurance company that doubts the validity of the statistics on which it bases its premiums and, therefore, questions the economic efficiency of using the insured person's sex as a predictive variable has a great incentive to act on this doubt. It could profit by using other, more economically efficient predictors. Indeed, some insurers have attempted to target their policies more precisely by offering lower premiums to nonsmokers, for example. But the fact that no insurance company offers life insurance or annuities to individuals priced on the basis of merged-gender mortality tables is evidence either that no company cares to take competitive advantage of this "information," that they are uniformly incapable of recognizing that the mortality data are wrong, or that Professor Brilmayer and her colleagues are incorrect in their conclusions about the demographic evidence. It therefore appears necessary to review the demographic evidence once again.

\section{The Relationship Between Gender and Mortality}

I agree with the Rejoinder's conclusion that the existence of a genetic or biological advantage is legally irrelevant. ${ }^{46} \mathrm{I}$ also agree both that research has not established that biological differences between females and males are the sole cause of the sex mortality differential ("SMD") and that environmental factors play an important role. ${ }^{47}$ Indeed, it should not matter what the causes of the

15 H. Dingman, Risk Appraisal 173-74 (2d ed. 1954); Benston, supra note 7, at 530. Additional evidence that using sex-distinct mortality tables is not discriminatory comes from the lower rates charged to females under age 30 for automobile accident insurance as well as from the fact that sex is not used as a predictor in the pricing of homeowners and other property insurance. See Nondiscrimination in Insurance: Hearings on H.R. 100 Before the Subcomm. on Consumer Protection and Finance of the House Comm. on Interstate and Foreign Commerce, 96th Cong., 2d Sess. 185 (1980) (statement of Charles C. Hewitt Jr. on behalf of the American Academy of Actuaries, Risk Classification Committee).

4 Brilmayer, Laycock \& Sullivan, A Rejoinder, supra note 1, at 229.

17 See id. at 236-39. Brilmayer and her colleagues contend that "research has shown 
SMD are, as long as gender is an unbiased, efficient predictor of life expectancy when annuity premiums are calculated..$^{48}$ Professor Brilmayer and her colleagues, however, challenge the efficiency of gender as a predictor on the grounds that the demographic evidence does not support a biological difference in longevity, that the SMD is unstable over the time period relevant to annuities, and that the current SMD will continue to fluctuate in the future. ${ }^{49}$

\section{A. The Biological Difference in Mortality}

The Rejoinder ${ }^{50}$ correctly devotes much attention to Madigan's study of Roman Catholic Brothers and Sisters, ${ }^{\text {s1 }}$ since it is important research that includes consideration of the life expectancies of people over age sixty ${ }^{52}$ - the only people for whom the Manhart decision is relevant. They incorrectly state, however, that "more recent studies have concluded that Madigan's research design was flawed by the fact that the Brothers had access to liquor and cigarettes," ${ }^{33}$ citing Waldron, among others. ${ }^{54}$ In fact, Waldron

that it is difficult, if not impossible, to determine the relative magnitude of any biological component of the SMD." Id. at 236 (footnote omitted). In support of this statement, they cite I. Waldron, The Role of Genetic and Biological Factors in Sex Differences in Mortality 21-25 (Dec. 1981) (unpublished paper presented at a conference sponsored by the World Health Organization and Australian National University, Sex Differentials in Mortality: Trends, Determinants and Consequences, Canberra, Australia, on file with The University of Chicago Law Review). Waldron, however, does not dismiss genetic causes of mortality differences between females and males. Indeed, after an extensive review of the relevant research in the area, she concludes: "The evidence presented indicates that a variety of genetic factors contributes to sex differences in mortality." Id. at 24 . I claim no more.

48 The biological link between sex and mortality is important only insofar as it provides evidence that the measured relationship between sex and mortality is not likely to be due to temporary environmental conditions or to invidious or stereotype-determined bias on the part of the demographers who gathered mortality data and the actuaries who used those data to calculate gender-specific life expectancies for life insurance premium calculations.

6 Brilmayer, Laycock \& Sullivan, A Rejoinder, supra note 1, at 236.

so Id. at $237-39$.

s1 Madigan, Are Sex Mortality Differentials Biologically Caused?, 35 Mribank MemoRIAL Fund Q. 202 (1957).

B2 See id. at 216.

ss Brilmayer, Laycock \& Sullivan, A Rejoinder, supra note 1, at 237 (footnote omitted).

st Waldron, An Analysis of Causes of Sex Differences in Mortality and Morbidity, in The Fundamental Connection Between Nature and Nurture 69, 105 n.4 (W. Gove \& G. Carpenter eds. 1982) [hereinafter cited as Waldron, Analysis of Causes]. The Brilmayer group, before discussing Madigan's study, asserts that "researchers who conclude that there is a biological component believe it to be small." Brilmayer, Laycock \& Sullivan, A Rejoinder, supra note 1, at 236 (footnote omitted). In support they cite Pressat, Surmortalite biologique et surmortalité sociale, 14 Revue FrançaIse de Sociologe 103, 105 (Numero Special 1973). However, as Professor Waldron points out, Pressat based his tentative suggestion on data derived from preindustrial Europe that did not permit him to separate environmental factors from genetic factors. I. Waldron, supra note 47, at 23. The Brilmayer 
did not present contrary findings, but merely opined that the SMDs that Madigan found could have been due to differences in the subjects' smoking, drinking, and early socialization. ${ }^{\mathrm{s}}$

Brilmayer and coauthors once more ${ }^{56}$ dismiss Madigan's finding of a significant difference in the mortality of similar males and females on the basis of their assumption that the Brothers smoked and drank more than the Sisters..$^{57}$ I already have presented data showing that even if this behavorial difference actually existed, it could not explain the difference in mortality between the otherwise similar males and females. ${ }^{58}$ Furthermore, this assumption ${ }^{58}$ about radical differences in the personal habits of the Brothers and Sisters is inconsistent with the understanding of the researcher who not only gathered the data but also was personally acquainted with

group also cites "[s]imilar conclusions by other investigators." Brilmayer, Laycock \& Sullivan, $A$ Rejoinder, supra note 1 , at 236 n.98. They refer to sources cited in their earlier article, Brilmayer, Hekeler, Laycock \& Sullivan, Sex Discrimination, supra note 1, at 541 n.177, including S. Preston, Ozder Male Mortality and Cigarettre Smoking 100 (University of Cal. Population Monograph No. 7, 1970); R. Retherford, The Changing Sex DipPERENTIAL IN MORTALITY 101 (1975); Enterline, Causes of Death Responsible for Recent Increases in Sex Mortality Differentials in the United States, 39 Mmbank Mgmorial Fund Q. 312, 325 (1961); Waldron, Why Do Women Live Longer Than Men?, 10 Soc. Scr. \& MED. 349, 349 (1976) [hereinafter cited as Waldron, Why Do Women Live Longer?]. These authorities, however, dispute the causes of SMDs rather than the fact that women live longer than men. Waldron, in fact, begins her study by noting that in 1970, a woman's life expectancy was almost eight years longer than a man's life expectancy. Id.

${ }^{8 s}$ Waldron, Analysis of Causes, supra note 54, at $105 \mathrm{n} .4$. In the note cited, Waldron merely repeats her earlier hypothesis concerning smoking and drinking, see Waldron, Why Do Women Live Longer?, supra note 54 , at 349 , and adds early socialization as a possible influence. She and the Brilmayer group choose to ignore Madigan's statement that "the life of the young Sisters seems to be slightly more stressful." Madigan, supra note 51, at 204. Furthermore, the relevance of early socialization escapes me, since both Brothers and Sisters chose to enter religious orders where they led similar, highly regimented lives.

so The same assumption was made in their first article, Brilmayer, Hekeler, Laycock \& Sullivan, Sex Discrimination, supra note 1, at 550.

${ }^{87}$ Madigan merely states that "[i]t must be admitted that the Brothers are more likely to smoke and to take an occasional drink." Madigan, supra note 51, at 204. Brilmayer and her colleagues say that Madigan noted that "overeating and obesity were not controlled." Brilmayer, Laycock \& Sullivan, A Rejoinder, supra note 1, at 237 n.102. In fact, Madigan's complete statement is as follows:

An important factor that is not controlled because of the absence of relevant data is the relative incidence of obesity or of overeating within each sex group. However, it may be observed that Sisters do not have the same motives for slimness found among their sex in the general public.

Madigan, supra note 51, at 205.

s8 Benston, supra note 7, at 521-23. I observed that the Sisters lived longer than the Brothers did in the years before cigarette smoking became popular, id. at $522 \mathrm{n} .94$, and that the SMD between Sisters and Brothers increased over time, id. at 522 (Table 3).

Bs See Brilmayer, Laycock \& Sullivan, A Rejoinder, supra note 1, at 237-38. 
the lifestyles of the people he studied..$^{60}$ The Rejoinder also puts forth a new argument that the Sisters who lived longer than the Brothers were a hardier lot due to earlier (1900-1919) higher mortality rates among the younger Sisters. ${ }^{61}$ But as Madigan explains, the effect was not likely to be large, and in any event, this factor does not explain why those Sisters who were not adversely affected during the earlier period also experienced longer lives than did Brothers of the same age. ${ }^{.2}$ Thus I believe that Madigan's study

so In response to my request that he comment on the Brilmayer group's criticism of his study, Father Madigan, S.J., writes:

First, my study controlled for many cultural factors which differentiate the life environment of most adultt [sic] men and women of the general population with the following research design point in mind: if cultural factors pertaining to adult life differentiate men and women of the general public, rather than biopsychic factors, then the mortality of men and women in my sample should draw closer together than the differential observed in the general public. In fact, the mortality of the two sexes, despite the great number of cultural factors that had been controlled, drew further apart. From the nature of the research design, I concluded that biopsychic factors appear to be more important [in] (NOT entirely responsible for) ... the resulting differential sex mortality.

Secondly, with regard to smoking and drinking on the part of Brothers, my dissertation did not analyze cause of death data (lung cancer, cardiovascular-renal incidence among the causes of death), and I am unable to say anything statistically relevant to the criticism relating to this point. However, my impressions are that teaching Brothers of the Catholic Church religious organizations would[,] by the nature of their occupation (teaching) and of their organizational affiliation as Brothers[,] be less likely to smoke or drink beyond what would have been considered moderation for their times in the general public. They would have to obtain cigarettes from their superiors in religion (i.e., their religious organization), and would presumably do most of any drinking they did with religious associates of their organization. Exceptions of course might occur, but I think this would hold for the large majority of the Brothers. It is of course median and average cases that we must argue from in a statistical fashion-or from quartiles, etc. I feel that these two comments should be kept in mind in evaluating my work. I believe that the smoking and drinking that would have occurred among the Brothers would be less than that characterizing men of the general white population of those decades involved in my dissertation. Thus the mortality rates should have equalled out more rather than diverged if the cultural hypothesis were in fact the more correct hypothesis. The fact that they not only did not converge somewhat but diverged more widely appears rather conclusive. . . .

I merely add that my impressions of the life the Brothers and Sisters lead is based upon my life with them during the course of my dissertation work (I usually was lodged with the Brothers, and was put up in a priest's room or house at the Sisters' headquarters). I also judge on the basis of my own life as a member of a religious congregation.

Letter from Reverend Francis C. Madigan, S.J., to Professor George J. Benston (undated) (on file with The University of Chicago Law Review) [hereinafter cited as Madigan letter]. 61 See Brilmayer, Laycock \& Sullivan, A Rejoinder, supra note 1, at 238.

62 Madigan writes:

If it were true that surviving Sisters from the 1900-1919 decades would have been the more hardy ones from earlier times and accounted for the better Sisters' rates in the later decades, this might account for a small part of the differential at the later decades in expectation of life at age 15 . I doubt however that the effect would be at all large. 
still provides important and valid evidence that the greater experienced longevity of females has some biological basis and is not simply an environmental peculiarity.

\section{B. The Stability of Male and Female Mortality}

Professor Brilmayer and her colleagues present some figures that they say demonstrate that SMDs are unstable. They are correct. Neither the life expectancy of males nor of females has been perfectly stable over long or even short periods of time, though the data they present show very little change over periods of about ten years. ${ }^{\text {es }}$ The real question, however, is not whether life expectancies are static over decades, but whether it is more accurate for an actuary to predict that a female of a given age will live longer than a male of the same age or to predict that they will live for the same number of years.

The tables Professor Brilmayer and her coauthors present ${ }^{64}$ and that I presented in my previous paper ${ }^{65}$ demonstrate clearly that life expectancy is significantly and consistently related to gender. Similarly, Chart 1, drawn from data recently released by the social security board, indicates that the SMD is significant, relatively stable, and expected to widen. Moreover, no one has shown the likelihood of any changes in the environmental causes of death related to gender that would reduce the measured relationship between gender and mortality during the period in which annuities are paid. For example, demographers predict that increasing female participation in the work force, an important environmental change, is unlikely to reduce female longevity. ${ }^{66}$

First, death rates at the higher ages have not improved greatly between the sexes beyond age 65 , as far as I know. Secondly, expectation of life at age 15 takes into account the mortality of all persons 15 years of age and over. Why were the Sisters 15-44, 45-64 also advantaged in comparison with men, in this culturally fairly well matched population, in the decades 1920-1954?

Madigan letter, supra note 60.

-3 See Brilmayer, Laycock \& Sullivan, A Rejoinder, supra note 1, at 240, 242-43.

o Id.; see Brilmayer, Hekeler, Laycock \& Sullivan, Sex Discrimination, supra note 1, at 543 n.183.

os Benston, supra note 7, at 515 (Table 1), 516 (Table 2), 522 (Table 3), 523 n.94, 527 (Table 4).

of "[F]or both chronic conditions and mortality, available data indicate that employed women are healthier than housewives, and the differences between employed women and men are even greater than the difference between housewives and men." Waldron, Analysis of Causes, supra note 54, at 94 (Table 6-5). "Additional evidence that the employment of women is probably not a key determinant of sex differences in mortality is provided by the finding that countries with higher labor force participation rates for women have not had smaller sex differences in mortality." Id. at $105 \mathrm{n} .4$ (citations omitted). 


\section{CHART 1}

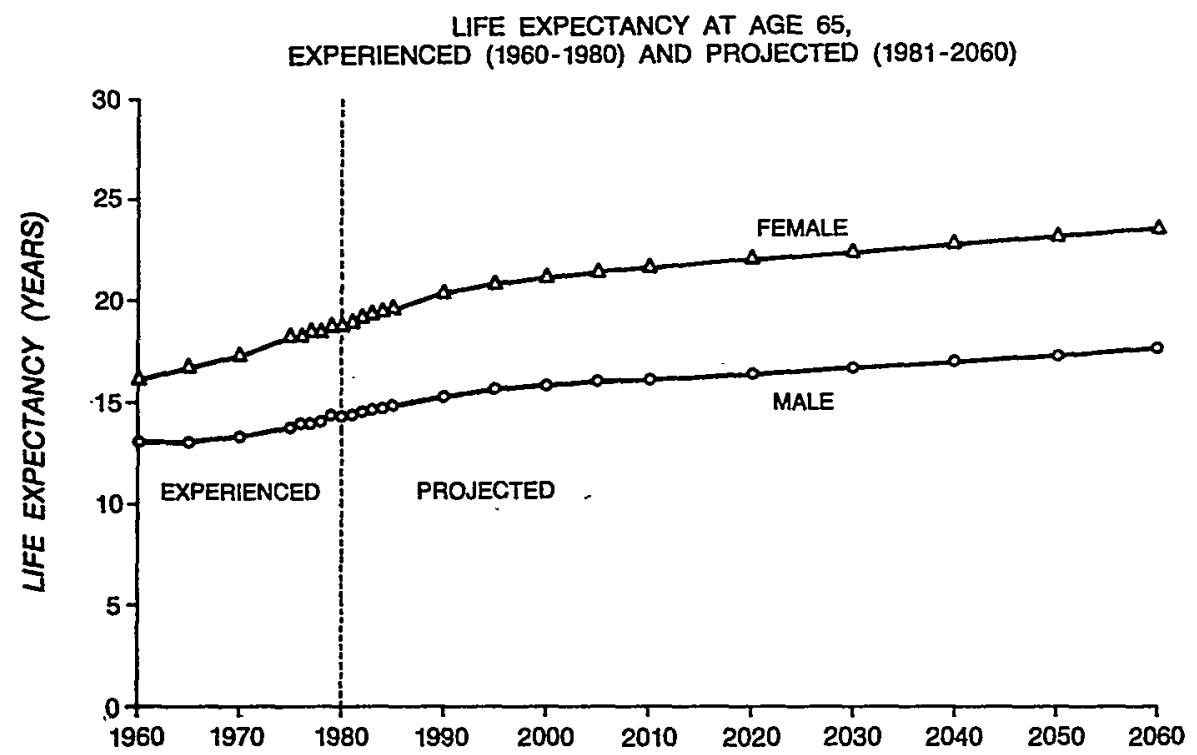

Source: Board of Trustees of the Federal Old-Age and Survivors Insurance and Disabihtsy Insurance Trust Funds, Annual Report 35 (1982) (Table II) (projected according to alternatives II-A and II-B).

In challenging the stability of SMDs, Brilmayer and colleagues also discuss the statistical relationship between various causes of death and the gender of the deceased persons. ${ }^{67}$ Presumably the discussion is supposed to demonstrate the changing causes and incidence of death among males and females, and thereby to cast doubt on the stability of the SMD. But they miss the point. The problem faced by actuaries is to predict the life expectancy of a person who wishes to purchase an annuity. An annuity, like other insurance, is an aleatory contract: the buyer pays a fixed premium, in return for which the insurance company assumes the obligation of paying a specified amount per period (or some other method of payment) so long as the annuitant lives. Should the annuitant outlive the expected period, for any reason, the insurance company still is obligated to pay the annuity benefits as originally promised. The point, then, is not whether life expectancies are perfectly stable, but whether predictions can be made for each insured more 
effectively by disregarding gender. The data Brilmayer and coauthors present support rather than refute the present practice of using gender as a predictive variable to price annuities and life insurance. They neither show that mortality is changing so rapidly as to make individual predictions more accurate when gender is disregarded, nor do they show how an insurer could identify those specific males or females whose life expectancy differs due to self-destructive behavior or non-sex-linked genetic determinants of mortality. Furthermore, they present no evidence to support their assertions that insurers' use of sex-distinct mortality tables is a "sexual stereotype" or a result of deliberate or inadvertent bigotry. Nor can they argue that the continued use of these tables reinforces damaging stereotypes about females, since few people consider longer life to be bad. Under these circumstances, any legislative or judicial determination that the use of sex-distinct mortality tables is to be prohibited should at least consider the distributional consequences of such a rule, as well as the unique position of insurance (a product that depends on efficiently made predictions) in discrimination law.

\section{Discrimination and Social Policy}

A. The Statutory Prohibition Against Invidious Discrimination

Neither the Supreme Court ${ }^{88}$ nor the Brilmayer group appears to recognize that annuities and insurance generally are zero-sum games. All of the premiums collected, plus earnings from invested funds, less administrative expenses and reserves for contingencies, are paid to policy holders. ${ }^{68} \mathrm{~A}$ blanket legal prohibition against sex-distinct mortality tables does not change the fact that a policy holder's gender is meaningfully predictive of her or his expected death. ${ }^{70}$ If the law forbids the use of such tables, greater annuity benefits will have to be paid to each individual female, and lower benefits to each individual male; this result is clearly invidious discrimination against men on the basis of their sex.

I conclude, then, that just as it is ethically justified for legislation to prohibit invidious discrimination against a person because she is female, it should be equally unethical to impose by law an invidiously discriminatory cost on a person because he is male. This implication of the Manhart decision, however, does not seem

68 In City of Los Angeles v. Manhart, 435 U.S. 702 (1978).

69 Stockholder-owned companies also pay dividends to shareholders.

70 See generally supra part III. 
to have been recognized by the Court or by Professors Brilmayer, Laycock, and Sullivan. Nor does the effect on females of a prohibition against the use of sex as a predictor for insurance (and other purposes) appear to be understood, for the result generally will be harmful to females. This aspect of the Manhart decision, and its possible extension, is considered next.

\section{B. The Effect of Legally Prohibiting the Use of Sex-Distinct Mortality Tables}

If employers are not permitted to use sex-distinct mortality tables to calculate annuities (or to contract with insurers who do so), they will be forced to pay their present female employees higher wages in the form of increased annuity contributions on their behalf. I explored the consequences of this change in my previous paper. ${ }^{71}$ There I showed that fewer women would be employed and that pension funds would suffer from adverse selection as men found ways to avoid the penalty inherent in merged-gender mortality tables and females found ways to benefit from this reallocation of wealth. ${ }^{72}$ Rather than repeat the reasoning given there (which Brilmayer and her coauthors have not attempted to refute), I proceed to consider who would benefit from and who would pay for a change to integrated mortality tables.

If sex-distinct mortality tables could no longer be used to calculate annuity premiums and benefits, now-retired females (and their beneficiaries) would gain considerably, getting an unanticipated windfall. Retired males (and their predominantly female beneficiaries) would lose what the females gain. ${ }^{73}$ Currently-employed females also would gain (at least temporarily) as their total compensation package would be increased by this adjustment of

72 See Benston, supra note 7, at 532-41.

72 For example, some plans include the option of allowing retired employees to "cash out"- to take a portion or all of the retirement fund in cash or as a transfer to another fund or insurance company. In plans with this option, male employees would benefit from leaving. The proportion of females would increase until eventually the pool of annuitants would consist entirely of females, and their periodic payments would be the same as if sex-distinct mortality tables still were used. Id. at 540.

${ }^{73}$ The Teachers Insurance and Annuities Association ("TIAA") and College Retirement Equities Fund ("CREF") are principal codefendants in a number of lawsuits involving allegations of sex discrimination in annuity plans. See, e.g., Spirt v. Teachers Ins. \& Annuity Ass'n, 691 F.2d 1054 (2d Cir. 1982), petition for cert. filed, 51 U.S.L.W. 3394 (U.S. Nov. 9, 1982) (No. 82-791). TIAA-CREF's pension plan includes money voluntarily contributed by many of the plan's participants for their own and their dependents' benefit. The relief sought by the plaintiffs in Spirt would result in a recalculation of the benefits purchased by these funds as well as of those that were accumulated in accordance with the basic plan. 
their benefits. But at least one of three potential changes would follow. Some employers would drop or modify their pension plans, other elements of the females' wage packages would decrease, or fewer females would be employed. Retired females would be benefited but employed females would bear the costs of these results, as would employees who would have preferred an employer-sponsored pension plan. In addition, insurance companies would incur costs in rewriting policies and in attempting to estimate the potential cost of adverse selection. When this cost is passed on, premiums would increase and net benefits would decrease.

If the use of sex-distinct tables were forbidden for all insurance (not just that provided as an employment fringe benefit), as would be required were the Fair Insurance Practices Act ${ }^{74}$ enacted into law, females in general would be disadvantaged. At present, females (that is, each individual person who happens to be a female, not only females as a group) pay lower premiums than similarly situated males pay for life insurance and, for females under age thirty, automobile accident insurance. These lower rates are based on the same sort of statistical relationships as are used to determine annuity premiums. Indeed, while there is some evidence of a biological relationship between mortality and gender, ${ }^{75}$ there is none for automobile accidents. The impact on the premiums of individual males and females if sex-distinct tables and higher premiums for pregnancy coverage were legally banned was calculated by the American Academy of Actuaries. ${ }^{76}$ Tables 1 and 2, reproduced from their report, show both the percentage and dollar amounts of the changes that would occur and the differing amounts now paid by similarly situated males and females. In the aggregate, females annually would pay $\$ 1060$ million more for life and automobile insurance, $\$ 92$ million more for full maternity coverage, and $\$ 106$ million less for regular medical and disability insurance, for a net increase of $\$ 1046$ million. ${ }^{77}$

${ }^{74}$ S. 2204, 97th Cong., 2d Sess. (1982).

78 See generally supra part III.

7o See Hearings on S. 2204 Before the Senate Comm. on Commerce, Science and Transportation, 97th Cong., 2d Sess. 8-9 (1982) (statement of the American Academy of Actuaries, Committee on Risk Classification) (on file with The University of Chicago Law Review) [hereinafter Hearings].

77 Id. at 9. 


\section{TABLE 1}

Estimated Percentage Erfect on the Average Prices Paid by Individual Male and Female Purchasers of Insurance Products If Gender May Not Be Used as a Predictive Variable

\begin{tabular}{|c|c|c|c|c|c|c|}
\hline \multirow[b]{3}{*}{ TYPE of INSURANCE } & \multicolumn{6}{|c|}{$\begin{array}{l}\text { Percentage Change in Price } \\
\text { Increase (+) Or Decrease (-) }\end{array}$} \\
\hline & \multicolumn{3}{|c|}{ MaLE } & \multicolumn{3}{|c|}{ Female } \\
\hline & Age 20 & 0 Age 40 & Age 65 & Age 20 & 0 Age 40 & Age 65 \\
\hline Life Insurance & -2 & -3 & $\mathrm{~N} / \mathrm{A}^{\mathrm{a}}$ & +6 & +11 & $N / A^{a}$ \\
\hline \multicolumn{7}{|l|}{ Health Insurance } \\
\hline \multicolumn{7}{|l|}{ Medical Expense } \\
\hline Unisex Rating & +18 & +13 & 0 & -12 & -7 & 0 \\
\hline Full Maternityb & +38 & \pm 1 & 0 & $\underline{+26}$ & +1 & 0 \\
\hline Total & +56 & +14 & 0 & +14 & -6 & 0 \\
\hline \multicolumn{7}{|l|}{ Disability } \\
\hline Unisex Rating & +4 & +2 & 0 & -26 & -21 & 0 \\
\hline Full Maternityb & +20 & $\underline{0}$ & 0 & +20 & $\underline{0}$ & 0 \\
\hline Total & +24 & +2 & 0 & -6 & -21 & 0 \\
\hline Automobile Insurance ${ }^{c}$ & -20 & $0^{d}$ & 0 & +37 & $0^{d}$ & 0 \\
\hline Individual Annuities $\mathbf{e}^{\mathbf{e}}$ & +6 & +6 & +6 & -6 & -6 & -6 \\
\hline
\end{tabular}

Source: Hearings, supra note 76, at 8 (statement of the American Academy of Actuaries, Committee on Risk Classification) (on file with The University of Chicago Law Review).

a Relatively little life insurance is sold on an individual basis to people age 65 .

$b_{T h i s}$ is the result of requiring full maternity coverage (i.e., coverage for normal pregnancies and deliveries, as well as coverage for complications of pregnancy).

c Effects shown are for men and women who are principal drivers of the insured car.

$\mathrm{d}$ Some insurers now charge women between the ages of 30 and 64 who are the sole operators of their cars approximately $10 \%$ less than they charge similarly situated men. The price of auto insurance for these women would increase slightly, but the impact is difficult to predict and would be small in any event.

e Payments commencing at age 65, with refund features. 
TABLE 2

Estimated Annual Aggregate Dollar Egfect on the Average Prices Paid by Individual Male and Female Purchasers of Insurance Products if Gender May Not be Used as a Predictive Variable

\begin{tabular}{lcc}
\hline \hline & \multicolumn{2}{c}{$\begin{array}{c}\text { Aggregate Annual Cost Impact (\$ in millions) } \\
\text { Increase ( }+ \text { ) }\end{array}$} \\
\cline { 2 - 3 } Typ Decrease ( $)$
\end{tabular}

SouRCE: Hearings, supra note 76, at 9.

The effects of merged-gender mortality tables for annuities are difficult to assess. Similarly situated males and females would get the same monthly payments. Because there is no reason to expect the total fund to change, payments to females would increase, and those to men would decrease. ${ }^{78}$ Initially then, females would benefit and males would lose. Most pensions, however, support the retiree and her or his dependents, who usually are of the opposite sex; reduced benefits to males therefore also would reduce the amounts paid to their female dependents.

Finally, the effect of requiring merged-gender mortality tables on the provision of insurance should be considered. Although Congress and the courts can make certain practices unlawful, they cannot prevent individuals from attempting to maximize their resources. All other things being equal, an individual female still will tend to outlive an individual male, and as a group, females will outlive males, facts that are not altered by requiring the use of merged-gender mortality tables. ${ }^{79}$ As a consequence, females would

78 Even if the total fund were to increase, equality in benefit payments is likely to be offset by other changes in compensation. See Benston, supra note 7, at 534-36.

7* Professor Brilmayer and her colleagues assert that when the mortality data are 
tend to purchase annuities and to shun life insurance, while males would do the reverse. Insurance companies would attempt to sell annuity policies to males, life insurance to females, and special gender-directed group policies to employers and associations. Large companies would tend to be self-insured, while small companies either would have to incur higher retirement expenses for their female employees or would have to compensate for the additional expense in other ways. Companies employing a majority of males would tend not to offer insured pensions as fringe benefits. These changes would result in considerable costs: the administrative expenses incurred to implement the changes, ${ }^{80}$ the higher insurance premiums charged to compensate for the increased risk of unexpected changes in the male-female composition of insured groups, and the costs to any employees who would be prevented from obtaining their preferred combination of wages and fringe benefits. The overriding social benefits that the expenditures are said to purchase are not at all evident, particularly since both men and women will be the victims of sex discrimination when gender, an efficient predictor of mortality, is not used to determine premiums and benefits.

\section{ConcLusion}

If invidious discrimination were not practiced, deliberately or inadvertently, the use of an employee's race, sex, or age as a predictive variable would be no more or less unfair than use of that person's educational credentials, previous experience, or score on an intelligence test. The particular variables used would depend on

pooled, male and female expectancies are the same. Brilmayer, Laycock \& Sullivan, $A$ Rejoinder, supra note 1, at $226 \mathrm{n} .25$. This appears to be based on the assumption that life expectancy is determined by the data rather than the reverse, and is reminiscent of a similar statement made by another social scientist, Humpty Dumpty: "When $I$ use a word . . . it means just what I choose it to mean-neither more nor less." " L. CARroll, Through THE Looking Glass and What Alice Found There 124 (1916) (emphasis in original).

80 The American Academy of Actuaries estimates the administrative costs of implementing the Fair Insurance Practices Act over a two to three year period (midway between the shortest and longest estimates of implementation periods) as follows:

TYPE OF INSURANCE

Life Insurance

Health Insurance

Casualty \& Property Insurance

Retirement Plans

Total Costs
( $\$$ IN MILLIONS)

$\begin{array}{r}\$ 870 \\ 200 \\ 75 \\ 200 \\ \hline \$ 1,345\end{array}$

Hearings, supra note 76 , at 11 . If a shorter time period were required for implementation, the costs would be greater. 
their economic efficiency, that is, on the marginal increase in predicting the employee's value to the employer compared to the marginal cost of making the prediction. An employer's use of a particular variable is unfair to an individual employee only when that assessment understates the person's employment value. Basing the assessment on educational attainments or previous work experience rather than on sex or race does not alter the situation. Nor is it relevant that a personal attribute is immutable, since a person who did not have the opportunity of attending a prestigious university, who did not get valuable on-the-job training, or who was born with low intelligence or without musical talent is as disadvantaged as is a woman who cannot lift heavy weights or a black with a greater than average propensity to suffer from sickle cell anemia. Furthermore, economic efficiency is not an illegitimate criterion for an employer's decision as to which predictive variables to use, since in all aspects of the employment situation, a wealth-maximizing employer with no preference for bigotry would follow this criterion in discriminating among employees and choosing among products and investments.

In the particular case where someone accuses employers of invidious discrimination in their reliance on gender to predict life expectancy, the accuser must provide evidence of employer bigotry or the inefficiency of gender as a predictor. Professors Brilmayer, Laycock, and Sullivan have presented no evidence to show that employer use of sex-distinct mortality tables is a result of bigotry or that it is inefficient. Furthermore, when examined purely as a matter of social policy, a requirement that such tables be abandoned appears ill-advised because of the considerable costs the prohibition would impose and the discriminatory results that would flow from use of merged-gender tables. The data and arguments marshaled by the Brilmayer group are insufficient to justify such radical changes in present market arrangements. 